11. With the assistance of the Canadian Legal Information Centre, the Coalition should advocate the increased use of plain language drafting in Canada and serve as a resource to its members in the drafting of plain language documentation.

\section{CARRIED}

\title{
English thrives best without protectionism, teachers say
}

(Press release, National Council of Teachers of English)

Why do many teachers of English oppose the current movement to make English the official language of the United States? Because 'the aims and tactics of the language protection movement' and 'its potential consequences for students' worry many members of the profession, says Harvey A. Daniels. He is the editor of a new book on this controversy, developed by the Commission on Language of the National Council of Teachers of English.

In Not Only English: Affirming America's Multilingual Heritage, well-known scholars and teachers offer historical, linguistic and educational background on the issue that has sparked the current drive to amend state and federal constitutions to establish English as the official tongue. The authors contend that 'English-only' policies now in force in 16 states 'hold grave dangers for teachers and students of English' and for many other Americans. Among the twelve contributors are Dennis Baron, L. Elliot Judd, Roseann Dueñas Gonzalez, James C. Stalker, Geneva Smitherman, James Sledd, and Victor Villanueva, Jr.

In his lead essay, Daniels points to a paradox: while the United States has been plural and multilingual from its colonial beginnings, English has remained dominant out of civic necessity and now serves as a worldwide lingua franca. Nevertheless, the nation has seen a series of protectionist campaigns like the current efforts of the lobbying group U.S. English.

Daniels and other contributors point out that such efforts coincide with new waves of immigration, wars, or economic downturns that carry threats of unemployment. They say the ethnocentric rhetoric and negative stereotypes the campaigns produce are often trace- able to 'fear of the stranger' - new or 'enemy' population groups whom later generations often view as 'standard,' unhyphenated Americans. The authors warn that Englishonly campaigns foster a destructive antiimmigrant climate that isolates newcomers and denies them help with English. Analyzing the effects of a long-standing English-only law in Illinois, Dennis Baron contends it has delayed efforts to understand the needs of non-English speaking students and has excused schools for letting them sink instead of helping them swim.

The authors discuss the potential threat English-only laws pose to civil rights legislation of recent decades, to legal, health, and voter assistance for language minorities, and to freedom to read and to teach. They charge that proponents of language restrictions ignore current knowledge about the origins and meanings of language differences and the process of language change.

Daniels urges teachers to support the concept of 'English Plus' - a richer curriculum for English including descriptive and historical study of the language, plus the learning of other languages and advocacy of greater language assistance for all learners.

Gonzalez observes that the U.S. English lobbying group has chosen the easier route to a constitutional amendment by shifting its campaign from Congress to the states. She warns that if it succeeds, options such as bilingual education for teaching non-English speakers would be restricted and immigrants' chances of employment reduced. Stalker predicts that a logical result of English-only laws would be 'standard English-only' laws and a quagmire of litigation over whose English is standard. Smitherman contends that omission of cultures other than Anglo from U.S. education leaves students unprepared to appreciate the 'singular achievement' of America in human history or to function 
intelligently in today's world.

Not Only English sums up a consensus within NCTE and the English teaching profession that wider and deeper knowledge of English and other languages, not language restriction, is the route to progress in education and society.

(Not Only English: Affirming America's Multi- lingual Heritage, 1990, ëdited by Harvey A. Daniels. 135 pages, paperbound. Price: \$8.95; NCTE members, \$6.95. ISBN: 0-8141-3363-0. LC: 90-31354. Audience: National and state policymakers and education officials, school administrators and teachers. Available from NCTE, 1111 Kenyon Rd., Urbana, Illinois 61801. Stock No. 33630-0015.)

\section{The economic clout of the US copyright industries}

According to the conclusions of a recent study entitled 'Copyright Industries in the US Economy' (Economists Incorporated, Nov 90), commissioned by the US International Intellectual Property Alliance (IIPA), 'by virtue of the size and dramatic growth achieved by the US copyright industries in recent years, the continued health of these industries has become critical to the long term prospects of the US economy'.

With this study, IIPA, the anti-piracy alliance of the major US copyright industries computer software, motion picture, music, record and book publishing industries aimed at quantifying the impact of their business in the US economy and hence justify lobbying for US government assistance to improve the protection of copyright, at both national and international levels.

The conclusions of this study reveal the amazing performance of the US copyright industries. These include not only the 'core' copyright industries (i.e. publishing-related industries, computer programming and software, radio and TV broadcasting, advertising, motion pictures, theatrical productions, records and tapes), but also the partial copyright industries (i.e., household and consumer durables, fabric, stationery, photography, business products and services), distribution industries (i.e., transportation, trade, cable TV and satellite), and copyright-related industries (i.e. computers and radio and TV receiving sets).

'The copyright industries now contribute 5.8 percent of US Gross National Product (GNP), and they employ ... roughly 4.6 percent of the US work force. The copyright industries are now larger than either: US agricultural and mining industries combined; the construction industry; the transportation industry; or the combined food, textile and apparel, chemical and oil and coal refining industries. Since 1977, the copyright industries have experienced annual growth of 6.7 percent per year; during the same period, the remaining sectors of the US economy grew at only 2.7 percent annually. Since 1977, copyright industry employment has increased at an annual rate of 5.0 percent, while total US employment rose at a rate of only 2.0 percent. Moreover, in a time of dramatic trade deficits, ... . the 'core' copyright industries generated (in 1989) revenues from foreign sales of at least $\$ 22.3$ billion'.

According to the study, these figures justify that 'maintaining the competitiveness of the US copyright industries must be among the highest government objectives in preserving America's place in the world economy'. The authors ask for 'far stronger bilateral and multilateral efforts to improve copyright protection around the world and to dismantle other barriers to trade in intellectual property products generally' - particularly within the GATT negotiations.

Copies of this study can be ordered at the following address:

Mr. Eric Smith

International Intellectual Property Alliance 1300 Nineteenth Street, N.W., Suite 350.

Washington, D.C. 20036 - USA

Fax: 2028720546

(from the International Publishers Bulletin, Vol. 7, No. 1, 1991) 